\title{
THE CHOICE OF SIGNALS FOR HYDROACOUSTIC NAVIGATION SYSTEM OF TRANSFORMATION UNDERWATER APPARATUS TO DOCKING MODULE
}

Manuscript received 05 April 202I;

Revised 20 April 202I;

Accepted 17 May 2021

Boris I. Filippov,

Novosibirsk State Technical University, Novosibirsk, Russia,

Keywords: the hydroacoustic navigation system of transformation, autonomous underwater vehicle, filippov-boris@rambler.ru the docking module, navigation parameter

\begin{abstract}
The proposed work is the first part of the overall work on the development of the structure of the hydroacoustic navigation system (HNST) for bringing the autonomous underwater vehicle (AUV) to the docking module (DM). The second (final) part will be published in the next issue of the journal. The purpose of this work is to select signals for building HNST providing reduction in a near zone at the distances not exceeding $300 \mathrm{~m}$, an AUV and its docking with the carrier is considered. Mutual definition of a distance and angular position DM of the carrier and AUV relative to each other is carried out for this purpose. Determination of mutual angular coordinates can be carried out with use of HNST with short and ultra-short base. HNST with short base is preferable for realization from the point of view of simplicity. However, its installation on the AUV can be impossible because of rather small sizes of the device, and on AUV should be installed HNST with ultra-short base. HNST with short base can be established on the docking module. Since there are no reasons to assume the high speed of change of the phase characteristic of the developed high-frequency channel of transformation therefore the interval of stationarity of the phase characteristic should be significantly more than duration of a symbol at a speed of transfer of $4 \mathrm{kBit} / \mathrm{s}$. Therefore, it is advisable to exchange measurement data between AUV and DM in the composition of HNST by relative phase modulation (DPSM). Reception of signals is performed by a suboptimal incoherent receiver on which entrance deep restriction of an entrance signal is carried out. The use of deep signal limitation at the receiver input allows to exclude operation of automatic control of strengthening at a stage of entry into communication, as a result, it is possible to reduce the duration of communication sessions. In the combined information navigation system, it is expedient: to apply as navigation signals of data exchanged between AUV and DM based on the results of mutual measurement of navigation parameters; to carry out data exchange between AUV and DM by method DPSM with a speed $V=4 \mathrm{kBit} / \mathrm{s}$; to carry out transfer of the block of data with application of the correcting block cyclic code ; to apply to reception of a block of data diversity reception in combination with majority decoding characters, and then correct errors in the data block with the help of code, and to accompany the issuance of data to the user sign detection code errors in the block.
\end{abstract}

Information about author:

Boris I. Filippov, Novosibirsk State Technical University, Ph. D. in Technical Scinces, Department of Information Protection, Novosibirsk, Russia

\section{Для цитирования:}

Филиппов Б.И. Выбор сигналов для гидроакустической навигационной системы приведения подводного аппарата к стыковочному модулю // T-Comm: Телекоммуникации и транспорт. 202I. Том I5. №6. С. 56-64.

For citation:

Filippov B.I. (202I) The choice of signals for hydroacoustic navigation system of transformation underwater apparatus to docking module. T-Comm, vol. I5, no.6, pp. 56-64. (in Russian) 


\section{Introduction}

The proposed work is the first part of the overall work on the development of the structure of the hydroacoustic navigation system( HNST) for bringing the autonomous underwater vehicle (AUV) to the docking module (DM). The second (final) part will be published in the next issue of the journal.

The possibility of constructing HNST is being considered, which provides an AUV in the near-field zone at distances not exceeding $300 \mathrm{~m}$ and its docking with the carrier.

In [1, p. 183], the expediency of presenting the developed HNST in the form of a combined information and navigation system was shown. As navigation signals in such a system, signals can be used that are intended for exchange between DM and the AUV with measurement data of the slope distance, elevation and azimuth between them.

Determination of mutual angular coordinates can be carried out using GNSS with a short and ultrashort base. In both cases, the measured angular characteristics are "apparent", "measured along the beam". The slope distance obtained from the measurement of the propagation time of the acoustic signal between the AUV and the DM is also "apparent", since the signal propagates along the beam curved due to refraction. To pass to the actual values of the oblique distance and angular coordinates, their "apparent" values must be recalculated in accordance with the ray theory accepted in hydroacoustic, see, for example, [2]. For this purpose, the mutual determination of the distance and angular position of the DM of the carrier and the AUV relative to each other is carried out.

As a rule, AUV control is carried out on the basis of algorithms with a large set of coefficients and empirical dependencies [3-6]. This approach provides a solution in a number of special cases. In the course of a long autonomous movement of the APU, such algorithms lead to large errors. In [7], an algorithm for the optimal programmed-positional control of the AUV based on the theory of optimal control is shown, which excludes the procedure of empirical selection of coefficients in the control laws and allows the delivery of the payload to the docking object. In [8,9], it is proposed to use video information from mono cameras (or high-resolution scanning sonar) for the adaptive calculation of the trajectory of the robot. Given the limited transparency of the aquatic environment, the use of video cameras (or sonars) at distances of more than 50 meters is problematic. In [10, 11], navigation robotic systems are described, including autonomous underwater and surface vehicles. These complexes solve only navigation problems. In [11] it is shown that in field tests, the error in determining the coordinates of the AUV was 8-16 meters.

From the point of view of simplicity, HNST with a short baseline is preferred for implementation. But its installation on the AUV may turn out to be impossible due to the relatively small size of the apparatus, and the AUV should be equipped with a HNST with an ultrashort base. HNST with a short base can be installed on the docking module. Such a solution makes it possible, by carrying out additional space-time processing of communication signals on the DM, to improve the quality of the measurement data transmission from the AUV to the DM, which in the conditions of power constraints on the AUV is an undoubted advantage of this option for constructing highfrequency HNST equipment.

\section{Formulation of the problem}

Ensuring the required noise immunity of data reception in HNST can be achieved by choosing an appropriate signal system and applying appropriate methods for increasing the reliability of transmission, based on the use of various kinds of redundancy.

It is known that the maximum noise immunity of digital information transmission is provided when using orthogonal or opposite binary signals. Discrete frequency modulation (DFM) signals and discrete relative phase modulation (DPSM) signals are often used. The use of DPSM signals for digital information transmission provides almost two-fold savings in hardware costs compared to the use of DPSM signals [12]. Since there is no reason to assume a high rate of change in the phase characteristic of the developed high-frequency alignment channel, therefore, the interval of stationarity of the phase characteristic should be significantly greater than the symbol duration at a transmission rate of $4 \mathrm{kbit} / \mathrm{s}$, it seems expedient to exchange measurement data between the AUV and DM as part of the HNST by the DPSM method [12]. Signals are received by a suboptimal incoherent receiver, at the input of which a deep limitation of the input signal is carried out [13]. The use of deep limiting of the signal at the receiver input allows excluding the operation of automatic gain control at the stage of entry into communication, as a result, the duration of communication sessions can be reduced.

The session nature of the exchange between the AUV and the DM with measurement data of mutual navigation parameters presupposes the adoption of special measures to ensure reliable determination of the beginning of the data block on the receiving side. In connection, usually, for this purpose, immediately before the start of the information block of the transmission a special synchronizing start sequence; a decoder is used to extract it.

Since when the receiver detects the start sequence, it is considered that the measured data is being transmitted, when choosing the signal structure, measures should be taken to reduce the likelihood of a false detection of the start sequence (false alarm) $p_{\text {л тр }}$ in the absence of its transmission.

\section{Choosing a signal system that implements the principles HNST with short antenna base}

When analyzing the applicability of HNST with a short baseline, the value of the root-mean-square error in measuring the propagation time of an acoustic signal between the AUV and the DM $\sigma\left(\tau_{R}\right)$ was taken sequentially equal to 2,5 , and $10 \mu$ s [14].

When measuring the propagation time through the "requestresponse" system, their error $\sigma\left(\tau_{R}\right)$ is determined by two components: the error caused by the frequency drift of the master oscillator, and the error in the moment of signal detection by the receiver caused by the action of interference. We require that the measurement error caused by the drift of the master oscillator frequency be an order of magnitude less than the error at the moment of signal detection by the receiver. It was shown in [15], that

$$
\sigma_{c}\left(t_{0}\right)=\frac{\sigma\left(\tau_{R}\right)}{\sqrt{2,2}},
$$


and in the same place:

$$
\sigma_{c}\left(t_{0}\right)=T_{0} \cdot \frac{\delta_{k}}{\sqrt{2 \Phi\left(\delta_{k} \cdot \sqrt{h^{2}}\right)}},
$$

$\delta_{k}$ - the value of the normalized step of correcting the position of the output signals of the clock synchronization system (STS) relative to the symbol duration $T_{0}$;

$\Phi(x)$ - probability density function of a centered, normalized random normal Gaussian process

$$
\Phi(x)=\frac{1}{\sqrt{2 \pi}} \int_{-x}^{x} \exp \left\{-\frac{t^{2}}{2}\right\} d t,
$$

Substituting (1) into (2), we obtain an estimate of the required measurement data transfer rate between the AUV and the DM.

$$
\begin{aligned}
& V=1 / T_{0} \\
& V=\frac{\sqrt{2,2}}{\sigma\left(\tau_{R}\right)} \cdot \frac{\delta_{k}}{\sqrt{2 \Phi\left(\delta_{k} \cdot \sqrt{h^{2}}\right)}} .
\end{aligned}
$$

Table 1 shows quantitative estimates of the required data transfer rate between the AUV and the DM, based on the values of the propagation time measurement error $\sigma(\tau)=2$, 5 and 10 $\mu \mathrm{s}$, used in [14] when analyzing the use of HNST with a short baseline. The indicated quantitative estimates were obtained on the assumption of using an STS as part of a suboptimal receiver with a relative step size for correcting the position of its output signals $\delta_{k}=0,01$ and $\delta_{k}=0,005$.

Table 1

\begin{tabular}{|c|l|l|c|c|c|c|}
\hline \multicolumn{2}{|l|}{ Signal to noise ratio, $h^{2}$, decebel } & 10 & 20 & 30 & 40 \\
\hline \multirow{3}{*}{$\begin{array}{c}\text { Speed trans- } \\
\text { ferring data } \\
\text { between AUV }\end{array}$} & $\sigma\left(\tau_{0}\right)=2 \mu \mathrm{s}$ & $\delta_{k}=0,01$ & 33850 & 19015 & 11053 & 6497 \\
\cline { 2 - 7 } $\begin{array}{c}\text { и DM, } V \\
\text { Baud }\end{array}$ & $\delta_{k}=0,005$ & 23953 & 13126 & 7601 & 4238 \\
\cline { 2 - 7 } & $\sigma\left(\tau_{0}\right)=5 \mu \mathrm{s}$ & $\delta_{k}=0,01$ & 13540 & 7606 & 4421 & 2599 \\
\cline { 2 - 7 } & $\delta_{k}=0,005$ & 9580 & 5240 & 3040 & 1695 \\
\hline \multirow{2}{*}{$\sigma\left(\tau_{0}\right)=10 \mu \mathrm{s}$} & $\delta_{k}=0,01$ & 6770 & 3803 & 2211 & 1299 \\
\cline { 2 - 7 } & $\delta_{k}=0,005$ & 4790 & 2620 & 1520 & 848 \\
\hline
\end{tabular}

Estimation of the measurement data transfer rate between AUV and DM $V$, Baud, based on the measurement error of the propagation time $\sigma\left(\tau_{R}\right)$ at $\delta_{k}=0,01$ and $\delta_{k}=0,005$

Based on the conditions for minimizing the cost of implementing the equipment, the value of the transmission rate should be selected from the condition: $V=m \cdot 1000$ [Baud], where $m$ is an integer. It seems expedient (for reasons of reasonable complexity of the equipment) to consider the possibility of transmitting data between the AUV and the DM at 4000, 5000 and 6000 Baud rates.

Quantitative estimates of the error in measuring the propagation time for transmission $\sigma\left(\tau_{R}\right)$ rates of 4000, 5000, and 6000 Baud from the signal-to-noise ratio $h^{2}$ at the relative value of the correction step for the position of the STS $\delta_{k}=0,01$ and $\delta_{k}=0,005$, output signals and, given in Table. 2 , allow us to recognize it as expedient to organize the transfer of measurement data between the AUV and the DM as part of the HNST at speed $V=4000$ Бод.

At speed $V=4000$ Бод the permissible error in measuring the propagation time of the acoustic signal between the AUV and the DM $\sigma(\tau)=10 \mu \kappa c$ is provided at the signal-to-noise ratio $h^{2}=18 \partial \delta$, if an STS is used as part of the receiver with a relative value of the correction step for the position of the STS output signals $\delta_{k}=0,01$. If $\delta_{k}=0,005$, then the error in measuring the propagation time is provided $\sigma(\tau)=10$ мkc already at $h^{2}=12,5 \partial Б$.

Table 2

\begin{tabular}{|c|c|c|c|c|c|c|}
\hline \multicolumn{3}{|c|}{ Signal to noise ratio, $h^{2}$, decebel } & 10 & 20 & 30 & 40 \\
\hline \multirow{6}{*}{$\begin{array}{c}\text { Measurement } \\
\text { error of signal } \\
\text { propagation } \\
\text { time between } \\
\text { AUV and } \\
\text { DM, } \sigma\left(\tau_{0}\right) \text {, } \\
\mu \mathrm{s}\end{array}$} & \multirow[b]{2}{*}{$V=4000$ Baud } & $\delta_{k}=0,01$ & 16,9 & 9,3 & 6,6 & 3,2 \\
\hline & & $\delta_{k}=0,005$ & 11,9 & 6,6 & 3,8 & 2,1 \\
\hline & \multirow[b]{2}{*}{$V=5000$ Baud } & $\delta_{k}=0,01$ & 13,6 & 7,4 & 5,3 & 2,5 \\
\hline & & $\delta_{k}=0,005$ & 9,5 & 5,3 & 3,0 & 1,7 \\
\hline & \multirow{2}{*}{$V=6000$ Baud } & $\delta_{k}=0,01$ & 11,3 & 6,2 & 4,4 & 2,1 \\
\hline & & $\delta_{k}=0,005$ & 8,0 & 4,4 & 2,5 & 1,4 \\
\hline
\end{tabular}

Estimation of the error in measuring the propagation time for transmission rates of 4000, 5000, and 6000 Baud from the signal-to-noise ratio $h^{2}$ at $\delta_{k}=0,01$ and $\delta_{k}=0,005$

\section{Suggestions for choosing a signaling system for communication between AUV and DM in HNST}

Ensuring the required noise immunity of data reception in HNST can be achieved by choosing an appropriate signal system and applying appropriate methods for increasing the reliability of transmission, based on the use of various kinds of redundancy. It is known that the maximum noise immunity of digital information transmission is provided when using orthogonal or opposite binary signals. Frequently in these cases, discrete DFM signals or DPSM signals are used. It has been experimentally confirmed that the use of DPSM signals for transmitting digital information in a hydroacoustic communication channel provides a small, about $2 d B$, gain in noise immunity compared to DFM signals. In addition, when using DPSM signals to transmit digital information, almost two-fold savings in hardware costs are provided in comparison with the use of DFM signals [12].

Since there are no grounds for assuming a high rate of change in the phase characteristics of the developed high-frequency alignment channel, that is, the interval of stationarity of the phase characteristic should be significantly greater than the symbol duration at the transmission rate $V=4000$ Бод, it seems expedient to exchange measurement data between the AUV and the DM as part of the HNST using the DPSM method. In this case, the reception of signals is carried out by a suboptimal incoherent receiver, at the input of which a deep limitation of the input signal is carried out. The use of deep limiting of the signal at the input of the receiver makes it possible to exclude the operation of automatic gain control at the stage of entering into communication, by virtue of which it is possible to reduce the duration of communication sessions [15]. 
The session nature of the exchange between the AUV and the DM with measurement data of mutual navigation characteristics presupposes the adoption of special measures to ensure reliable determination of the beginning of the data block on the receiving side. In connection, usually, for this purpose, immediately before the beginning of the information block, a special synchronizing start sequence is transmitted, and a decoder is used to extract it. Since when the receiver detects the start sequence, it is considered that the measured data is being transmitted, when choosing the signal structure, measures should be taken to reduce the likelihood of a false detection of the start sequence (false alarm)

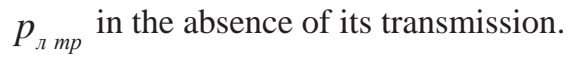

False detection of the start sequence can occur both as a result of its collection of noises in the absence of transmission in the channel, and as a result of the transformation of the data signal transmitted in the opposite direction, as well as back received at the input of the receiver as a result of reflection from a distant obstacle. Quantitatively, the frequency of recruiting a starting sequence from noises will be estimated by the probability of recruiting a starting sequence from noises $P_{\mathrm{нш}}$, and the frequency of transformation into a starting sequence of a data signal transmitted in the opposite direction will be estimated by the probability of transformation $P_{\text {тр }}$

$$
P_{\text {л тр }}=P_{\text {нш }}+P_{\text {тр }} .
$$

Taking into account that in the absence of a signal at the input of the receiver, the appearance of binary symbols "0" and "1" at its output is equally probable, then the set of the starting sequence with the length $L$ of symbols is carried out with the probability

$$
P_{\mathrm{Hш}}=2^{-L} \text {. }
$$

The probability of transformation $P_{\text {тр }}$ into the start sequence of a data signal transmitted in the opposite direction depends on the degree of their mutual difference. For definiteness, let us assume that the receiver detects a transformed start sequence from the data signal transmitted in the opposite direction. Taking this assumption into account, the minimum transformation $P_{\text {тр }}$ probability is ensured if mutually opposite sequences are used as starting data signals transmitted in opposite directions. In this case, the transformation probability is defined as:

$$
P_{\text {тр }}=p^{L}
$$

where $p$ - is the average error probability in the channel.

When using an optimal incoherent receiver for receiving DPSM signals, the average error probability is estimated by the value [16]:

$$
p=\mathbf{e}^{-h^{2}}
$$

In [15], it was proposed to use suboptimal incoherent receivers for the implementation of HNST, at the input of which a deep limitation of the received signal is carried out. Such a receiver loses $3 d B$ in noise immunity to the optimal incoherent receiver. Therefore, to estimate the average error probability in the channel, we will use the expression

$$
p=\mathbf{e}^{-\frac{h^{2}}{2}}
$$

In [17], it was shown that the signal transmission power in the channel should be selected so that the signal-to-noise ratio at the receiver input $h^{2}$ is not less than $12.5 \mathrm{~dB}$. Substituting the value $h^{2}$ into expression (3) and further into (2) and (1), we obtain

$$
P_{\text {лтр }} \approx 2^{-L} .
$$

Thus, when used for transmission in opposite directions between the AUV and the DM as part of the data signals of mutually opposite (inverse) start sequences, the probability of a false sequence detection is determined mainly by the probability of their collection of noises.

If we assume that unwanted commands can be issued to the AUV's autopilot due to a set of data block noises, the length of the starting sequence $L$ should be chosen such that the probability of its set of noises is negligible. We require that the probabilities of false reception of a data block in the absence of its transmission $P_{\text {л тр }} \leq 10^{-5}$. In this case, the length of the starting sequence must be selected from the condition $L \geq-5 \cdot \log _{2} 10 \approx 17$

The structure of the starting sequence should be chosen in such a way that its correlation function has a minimum level of side lobes. Of the currently known binary sequences, the best correlation properties are possessed by the Barker sequences [16], in which the lateral outliers of the normalized correlation function $r(l) \leq 1 / L$, where $L$ is the sequence length. However, the Barker sequences are of insufficient length and the Barker c sequences are known to date $L \leq 13$. For this reason, it is advisable to use M-sequences known in the communication technology [16] as a starting sequence. The normalized periodic correlation function of the M-sequence is

$$
r(l)= \begin{cases}1, & \text { при } l=0, \\ m_{i} / L, & \text { при } l \neq 0,\end{cases}
$$

where $m_{i}$ - is a constant, the value of which characterizes the maximum values of the lateral emissions of the correlation function of the $\mathrm{M}$ - sequence, has a value in the range from 0.75 to 1.25 .

The nearest length $L \geq 17$ required is an M-sequence with a length $L=31$. However, as will be shown below, it is more expedient to use an M-sequence with a length as a starting sequence $L=15$.

If, as noted, the detection of such a start sequence is carried out using a 15-bit decoder, then if at least one character in the sequence is distorted by noise, it will not be detected. The block of data received from the channel will be skipped. Quantitatively, the frequency of the receiver skipping a data block will be estimated by the probability of missing a target $p_{\text {пр ц }}$

$$
P_{\text {nр ц }}=1-(1-p)^{L} .
$$

Substituting into the value of the average error probability for $h^{2}=12,5 \partial Б$, we get that $p_{\text {пр ц }} \approx 2 \cdot 10^{-3}$. 
This estimate corresponds $p_{\text {пр ц }}$ to the steady state, when the phase of the output signals of the clock synchronization system has already been adjusted to the signal coming from the channel. However, in fact, at the beginning of the communication session, when the phase of the STS output signals has not yet been adjusted to the received signal, the probability of receiving a symbol with an error $\hat{p}$ approaches 0.5 . As the phase of the STS output signals is adjusted to the received signal, the estimate of the probability of receiving a symbol with an error $\hat{p}$ decreases and tends to the value of the average error probability in the channel $p$. The phase adjustment of the STS output signals to the received signal is carried out on average over the duration of the $\bar{L} \geq 50$ symbols. Therefore, strictly speaking, the estimate of the probability of missing a target $p_{\text {пр ц }}$ formulated in expression (4) is valid for the case when at the beginning of the communication session before the data block, the starting $m$ M-sequence (copies of the starting M-sequence) is transmitted once in a row. On the first four of them, the phase of the STS output signals is adjusted to the received signal, and the decoder detects the start sequence at the length of its subsequent copies. In fact, to reduce the likelihood of missing the start sequence, it is proposed to use repetition redundancy: multiple retransmission of the start sequence. The resulting ambiguity in determining the beginning of the data block (multiple of the length of the start sequence) is eliminated by transmitting, together with the start sequence, immediately after it, its serial number $m$. When the decoder detects the start sequence in the receiver, its sequence number is determined, according to which the moment of the start of the data block is calculated.

Thus, it is proposed to transmit a header immediately before the start of the data block, consisting of a series of noninterrupted numbered starting M-sequences 15 characters long.

When an M-sequence is detected in the header and its number is distorted by interference in the receiver, the beginning of the data block is incorrectly determined with consequences commensurate with the consequences of detecting a data block in the absence of its transmission. Therefore, we require that the probability of receiving the number of the starting M-sequence as part of the header with an undetected error in its number $P_{\text {но }}$ is quantitatively equal to the probability of false detection of the data block $P_{\text {л тр }}$. Let's accept $P_{\text {но }}=10^{-5}$. In this regard, to transmit the numbers of starting M-sequences in the header, it is advisable to use block correcting - codes $(n, k)$ that detect errors.

In this case, the probability of receiving a number with an undetected error can be reduced to an arbitrarily small value by increasing the number of check symbols $r=n-k$ in the corresponding code combinations; here $k$ - is the number of information symbols in the codeword, $n$ - is the length of the codeword.

When choosing the type of correction code, in addition to the probability $P_{\text {но }}$, it is necessary to take into account the degree of matching of the code with the channel characteristics, for which the parameters of grouping errors in the channel must be determined. With a lack of information about the grouping of errors in the channel in [17], it is recommended to use cyclic Bose -
Chowdhury - Hockwengham codes, which are distinguished by high detecting ability when working in communication channels with wide ranges of variation of the error grouping parameters. Another advantage of this class of codes is a simple, adapted for software implementation in an embedded microcomputer, regular procedure for encoding and decoding information, which makes it possible to recommend the use of cyclic Bose Chowdhury - Hockwengham codes in GNSS for transferring starting M-sequence numbers as part of the header.

The detecting ability of the correcting code, which is usually characterized by the multiplicity of guaranteed detected errors $t_{\text {обн }}$, is determined by the code distance $d$ of the correcting code $(n, k), t_{\text {обн }}=d-1$. As a rule, the code distance of the correction code grows with the increase of its redundancy $r$.

Considering the above, the signal header should have the structure shown in Figure 1.

\begin{tabular}{|c|c|c|c|c|c|c|c|}
\hline M-sequential & $m=1$ & M-sequential & $m=2$ & M-sequential & $m=3$ & M-sequential & $m=\mathrm{M}$ \\
\hline$L=15$ & $(15$, & $L=15$ & $(15$, & $L=15$ & $(15$, & $L=15$ & $(15,5)$ \\
\hline
\end{tabular}

Fig. 1. Structure of the data signal header

Below will be shown the feasibility of using for the transmission of numbers of starting M-sequences in the header of the block cyclic code of Bose - Chowdhury - Hockwengham $(n, k)=(15,5)$, with a generating polynomial $g(x)=x^{5}+x^{3}+x[18]$. The specified code has a code distance $d=7$ and can be guaranteed to detect six-fold errors, $t_{\text {обн }}=6$. It should be expected that the probability of undetected error when receiving numbers of starting $\mathrm{M}$-sequences in the header will not exceed the value $P_{\text {но }}=10^{-5}$ if the average error probability in the channel $p \leq 10^{-1} 1$.

Let us estimate the required number of retransmissions of start sequences in the header based $M$ on the probability of missing a data block $P_{\text {пр ц }}$. Taking into account that a time interval corresponding to the duration of two starting M-sequences and two code combinations of the cyclic code (15.5), which transmit the numbers of these sequences, should be reserved for adjusting the phase of the STS output signals to the incoming signal, we obtain a condition for determining the number of repeated transmissions of start sequences in the header $M$

$$
M \geq \frac{\lg P_{\text {пр ц }}}{\lg \left[1-(1-p)^{L+n}\right]}+2 \cdot
$$

For $P_{\text {пр ц }} \leq 10^{-5}$ and the signal-to-noise ratio at the input of the receiver $h^{2}=12,5 \partial D$, the header must contain at least five retransmissions of the starting $\mathrm{M}$-sequences and the corresponding code combinations of the cyclic code (15.5). The total length $L_{\text {заг }}=5 \cdot(15+15)=150$ of the binary character header.

Determination of the moment of the beginning of the data block is carried out by calculating the time interval $t_{\text {бл }}$ from the moment the decoder detects any of the five starting M-sequences 
and receives without errors the corresponding code combination of the code (15.5) with its number $m$. The specified time interval is measured in symbol durations $T=\frac{1}{V}$ and must be calculated according to the rule:

$$
t_{\text {бл }}=30 \cdot(5-m) \cdot T \text {. }
$$

Setting the header structure allows you to refine the estimate of the probability of a false detection of a data block due to a set of noises in the starting sequence. In the absence of transmission, a false detection of a data block can occur if the starting $\mathrm{M}$ sequence and the allowed combination of the cyclic code (15.5) are sequentially typed from the noise, intended for numbering the M-sequences in the header, such allowed code combinations are 31. Then, $P_{\mathrm{Hш}}=31 \cdot 0,5^{L+n}=31 \cdot 0,5^{30} \approx 2,9 \cdot 10^{-8}$, which is significantly lower than the accepted value $10^{-5}$.

The number $m$, received without errors in the starting $M$ sequence in the header, can be used for monitoring the quality of the functioning of the data exchange system between the AUV and the DM. If, in a number of consecutive data exchange sessions, start M-sequences with numbers $m$, mainly equal to "1" and "2", are found, then the quality of the functioning of the data exchange system between the AUV and the DM can be considered good. And vice versa, if in a number of sequential data exchange sessions the detected start M-sequences are predominantly numbered "5", then the quality of the system functioning should be recognized as close to critical, and measures should be taken to improve the transmission quality, for example, to increase the signal transmission power. That is, the information on the numbers of the received start $\mathrm{M}$-sequences in the header of the data signal can be used as an indirect measure of the signalto-noise ratio $h^{2}$ in the hydroacoustic channel to select a strategy for bringing the AUV to the docking module.

The mutual determination of the navigation characteristics of the AUV and DM relative to each other is accompanied by the exchange of measurement data between them. Data is transferred in 25-byte sessions. The average error probability when receiving the specified measurement data should be no worse than $10^{-4}$ per bit.

The quality of measurement data transmission to HNST is characterized by an average probability of error $P_{\mathrm{5}}$ per byte. For definiteness, we require that the average probability of error when receiving measurement data is no worse than $10^{-4}$ per byte.

Then, writing by analogy with expression (5)

$$
P_{\mathrm{Б}}=1-(1-p)^{8} \leq 10^{-4}
$$

we obtain that the equivalent average probability of receiving one symbol with an error in the data block must correspond to the value $p=1,25 \cdot 10^{-5}$. For comparison, let us note that the average probability of the error in receiving DPSM signals, calculated by expression (5) for the already mentioned signal-to-noise ratio $h^{2}=12,5 \partial Б$, is estimated by the value $1,36 \cdot 10^{-4}$. The resulting problem of reducing the probability of receiving a symbol with $p=1,25 \cdot 10^{-5}$ an error to can be solved by implementing diversity reception in HNST in combination with majority decoding of demodulated symbols as part of a data block.
In the considered HNST with a short baseline, from 4 to 8 channels for receiving navigation signals can be organized, as which in the HNST it is proposed to use data signals. Having several copies of the demodulated data signals received from the outputs of the receivers, separated in space by tens of wavelengths, it is possible, by additionally processing the mentioned copies of the demodulated signals, to make a decision on the meaning of each of the symbols in the data block by the "majority of votes" the equivalent average probability of receiving them by mistake. The gain in noise immunity of data reception is achieved by introducing hardware redundancy. The final equivalent average probability of receiving one symbol with $p_{\text {ош }}$ an error is estimated by the value [19]:

$$
p_{\text {ош }}=\frac{(2 k-1) !}{k !(k-1) !} p^{k},
$$

where $k$-is an integer, $k=1,2,3, \ldots$

$(2 k-1)=n-$ the number of diversity branches (number of receivers) used in the system to receive measurement data;

$p$ - the value of the equivalent average probability of erroneous reception of a symbol by one receiver.

Figure 2 shows the dependence of the final equivalent average error probability $p_{\text {ош }}$ on the number of diversity branches (the number of receivers used in the system) $n$ for different values of the equivalent average error probability of receiving a symbol by one receiver $p$.

The value of the final equivalent average probability of error $p_{\text {ош }}=1,25 \cdot 10^{-5}$, at which the required quality is ensured ( $P_{\mathrm{b}}=10^{-4}$ ) the exchange of measurement data between the AUV and the DM, is achieved at three times the space diversity with an equivalent average probability of receiving a symbol with an error $p=2,04 \cdot 10^{-3}$, which is 15 times greater than the average probability of receiving binary symbols with an error by a single receiver $p=1,36 \cdot 10^{-4}$ with a minimum signal-to-noise ratio in the channel $h^{2}=12,5 \partial 5$.

In order to increase the noise immunity of data reception, it seems expedient to additionally encode the transmitted blocks with a correction code that detects errors. This allows on the receiving side, after performing the majority decoding operation, by checking the received data block for errors, to reduce the probability of issuing invalid data for execution to a negligible value. The selection of the appropriate correction code is shown in figure 2.

The use of diversity reception in combination with majority decoding of symbols for data reception allows for a current assessment of the quality of the operation of the data exchange channel between the AUV and the DM by counting corrected errors based on a comparison of the output signals of the majority decoder of individual receivers used in the HNST. The number of corrected errors in the data block can be used as an indirect measure of the signal-to-noise ratio $h^{2}$ in the hydroacoustic channel to select a strategy for bringing the AUV to the docking module. 


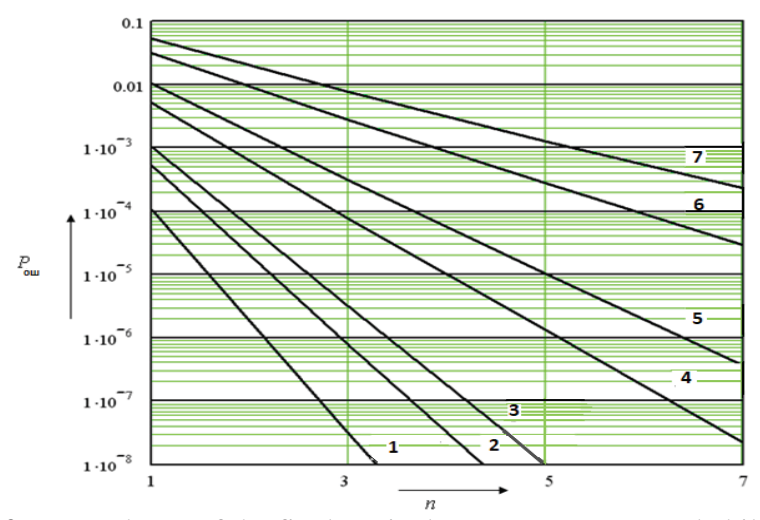

Fig. 2. Dependence of the final equivalent average error probability $p_{\text {ош }}$ on the number of explode branches $n\left(1: p=10^{-4} ; 2: p=5 \cdot 10^{-4}\right.$; 3: $\left.p=10^{-3} ; 4: p=5 \cdot 10^{-3} ; 5: p=10^{-2} ; 6: p=3 \cdot 10^{-2} ; 7: p=5 \cdot 10^{-2}\right)$

\section{Choosing a signal system that implements the principles HNST with ultrashort base antennas}

The basic principles of the session exchange of measurement data between the AUV and the DM do not depend on the type of navigation system used in the GNSS. Therefore, it seems reasonable to take as a basis when choosing a signal system for the implementation of a combined information and navigation system that implements the principles of HNST with an ultrashort base, the signal system selected for constructing an HNST with a short base, namely:

- de ermination of the slope distance is carried out by the "requestresponse" system using the data signal as a navigation signal;

- data exchange of measurement of mutual navigation parameters between AUV and DM is carried out by the DPSM method with a modulation rate of $4 \mathrm{kbit} / \mathrm{s}$;

- he data signal consists of a header and a data block;

- in turn, the header consists of a number of numbered start M-sequences, and diversity reception is used in combination with majority decoding to receive the data block;

- de ermination of the angular navigation parameters is carried out for the duration of the data block after the detection of the starting M-sequence.

Therefore, it is necessary to assess the achievable accuracy of measuring the propagation time of the acoustic signal between the AUV and the DM and the qualitative parameters of data exchange in the HNST with a signal-to-noise ratio of $8 d B$. A signal-to-noise ratio of $8 d B$ is considered as possible when operating in shallow seas, at maximum distances between AUV and DM.

The expected value of the root-mean-square error in measuring the propagation time of the acoustic signal between the AUV and the DM based $h^{2}=8 \partial Б$ on the relative value of the step for correcting the position of the output signals $\delta_{\mathrm{k}}=0,01, \sigma\left(\tau_{R}\right)=18,5 \mathrm{~ms}$ of the STS $\delta_{\mathrm{k}}=0,005, \sigma\left(\tau_{R}\right)$ is equal to $13,1 \mu \mathrm{s}$. , which is equivalent to the error in determining the slope distance $\Delta R=0,028 \mu$ и $\Delta R=0,02 \mu$, and can be considered quite acceptable [20].

\section{Quantitative assessment of indicators of the data exchange system between AUV and DM}

It should be expected that a decrease in the signal-to-noise ratio at the input of the receiving device to a value $h^{2}=8 \partial Б$ and, accordingly, an increase in the average probability of receiving a symbol with an error $p=4,3 \cdot 10^{-2}$ to can lead to an increase in the probability of the receiver skipping a data block $P_{\text {пр ц }}$, to an increase in the probability of receiving the number of the starting $\mathrm{M}$-sequence as part of the header with undetected error $P_{\text {но }}$ and an increase in the average final probability of receiving a symbol with an error in the data frame $p_{\text {ош }}$.

As already noted, the reception of the data block begins after the receiver detects at least one start $\mathrm{M}$-sequence and the corresponding code combination of the cyclic code (15.5) with the sequence number of the $\mathrm{M}$-sequence in the header. It is assumed that the decision about the start of the data block is made based on the detection by the receiver of one of the three starting M-sequences, designated in the header by the numbers "3", "4" and "5". If in all these starting M-sequences or the corresponding code combinations of the cyclic code (15.5) with their sequence numbers in the header, at least one symbol is distorted under the influence of interference, then the data block is skipped. You can write

$$
P_{\text {пр ц }}=\left[1-(1-p)^{L+n}\right]^{M-2} \text {. }
$$

Substituting the value of the average probability of receiving a symbol with an error for the signal-to-interference ratio $h^{2}=8 \partial Б$, we find that the probability of the receiver skipping a data block when the starting sequence is repeated five times in the header is estimated by the value $P_{\text {пр ц }}=0,39$.

Taking into account that the signal-to-noise ratio increases with a decrease in the slope distance $R$ between the AUV and the $\mathrm{DM}$, according to a law approaching the dependence of the type $1 / R^{2}$, it should be expected that as the AUV approaches the DM, the value of the signal-to-noise ratio $h^{2}$ at the receiver input will rapidly increase, and the probability the receiver skips the data block $P_{\text {пр ц }}$ decrease. However, given that data signals are used in HNST as navigation signals, it seems necessary to increase the number of retransmissions of start sequences in the header for reliable data transmission. If it is required that at the maximum slope distance between the AUV and the DM and the value of the signal-to-noise ratio at the receiver input $h^{2}=8 \partial \delta$, the probability of data skipping $P_{\text {пр ц }}$ was of the order of magnitude $10^{-2}$, then the number of retransmissions of the start sequences in the $\mathrm{M}$ header must be at least 24. To obtain $P_{\text {пр ц }} \approx 10^{-3}$ the number of retransmissions start sequences in the $M$ header should be at least 16. It seems appropriate to improve the performance of HNST to make the number of retransmissions of the start Msequences and the corresponding code combinations of the cyclic code (15.5) variable depending on the value of the signal/noise ratio or on the value $h^{2}$ associated with the estimate of the probability of error received when receiving the data block.

The specified adaptation for changing channel parameters is easy to implement if five start sequences are transmitted in the header in the channel of satisfactory quality $h^{2} \geq 12,5 \partial Б$ and numbered from " 1 ", say, to " 5 ". If the quality of the channel is low, $h^{2} \approx 8 \partial D$ send 16 or 24 starting sequences as part of the header and number them in the first case, numbers from "16" to 
"31", and in the second - numbers from "9" to "32". When a start sequence is found in the header, its number is determined and the duration of the time interval before the start of the data block is calculated according to the rule:

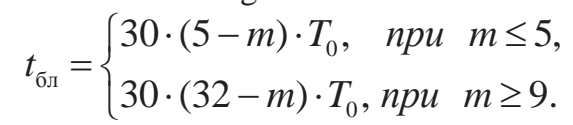

The quality of the exchange between the AUV and the DM of the navigation performance measurement data can be improved by using diversity reception in combination with majority decoding of the demodulated symbols. In the considered HNST with an ultrashort base, a five-fold diversity reception can be organized, which, in combination with majority decoding, allows, when operating at maximum distances, at $h^{2}=8 \partial Б$, to reduce the equivalent average probability of receiving a symbol with an error in the data block to $p_{\text {ош }} \approx 8 \cdot 10^{-4}$.

It seems expedient to use the cyclic Bose - Chowdhury Hockwengham code $(n, k)=(224,200)$ with a generating polynomial to encode data blocks $g(x)=x^{24}+x^{22}+x^{12}+x^{10}+x^{9}+x^{2}+x^{1}+1[21]$.

The specified code has a coding distance $d=6$, can be guaranteed to detect fivefold errors $t_{\text {обн }}=5$, correct double errors. The multiplicity of the corrected errors by the correcting code is equal to $t_{u c n p}=(d-1) / 2$; in our case $t_{u c n p}=2$. This means that the multiplicity errors will not be corrected $t \geq 3$ in the block distorted by noise. With an independent nature of errors, the probability of occurrence in the data block of errors with multiplicity $t \geq 3$ for does $h^{2}=8 \partial Б$ not exceed 0.014 . When organizing sevenfold diversity reception, the final probability of receiving a symbol with an error in the data block is reduced to a value $p_{\text {ош }}=1,2 \cdot 10^{-4}$, respectively, the probability of issuing a data block to the consumer with an error is reduced to a value $3,1 \cdot 10^{-6}$.

\section{Conclusion}

The analysis performed allows us to draw the following conclusions. In a combined information and navigation system, it is advisable:

- o use as navigation data signals, which are exchanged by AUV and DM based on the results of mutual measurement of navigation parameters;

- to c rry out data exchange between AUV and DM using the DPSM method at a rate of $V=4 \mathrm{kbit} / \mathrm{s}$;

- use he sequence of the header and the data block as the data signal transmitted in the channel;

- a ply a header consisting of a number of repeating starting 15-bit M-sequences and their corresponding numbers transmitted by the correcting block cyclic code (15.5);

- hange in the header the number of starting 15-bit M-sequences and their corresponding numbers, depending on the quality of the channel;

- o transfer the data block using the correcting block cyclic code (224, 200);

- apply div rsity reception in combination with majority decoding of symbols to receive a data block, then correct errors in the data block using a code, and accompany the data output to the user with a sign of detection of an error code in the block.

\section{References}

1. B.I. Filippov (2019). Digital transmission of information in hydroacoustic telemetry systems. Saratov: IPR Media. 290 p.

2. L.M. Brehovskih, Ju.P. Lysanov (1982). Theoretical bases of acoustics of the ocean. L.: Gidrometeoizdat. 264 p.

3. M.D. Ageev, B.A. Kasatkin, L.V. Kiselev i dr. (1981). Automatic underwater vehicles. L.: Sudostroenie. 224p.

4. V.F. Filaretov, D.A. Juhimec (2011). Method of formation of the program control by the speed mode of motion of the underwater vehicle along arbitrary spatial trajectories with a set dynamic accuracy. Izvestija RAN. Teorija i sistemy upravlenija. No. 4. P. 167-170.

5. L.V. Kiselev (1997). The organization of the spatial movement of the independent underwater vehicle at trajectory inspection of objects, areas of physical fields. Avtoreferat. dissertacii na soiskanie uchenoj stepeni doktora tehnicheskih nauk. spec. 05.13.01.

6. V.F. Filaretov, A.V. Lebedev, D.A. Juhmanec (2005). Devices and control systems of underwater robots. Moscow: Nauka. 213 p.

7. D.S. Kabanov (2014). Synthesis of an algorithm optimum programmatically - position control of the multi-mode automatic underwater vehicle. Mehatronika, avtomatizacija, upravlenie. No.1. P. 60-66.

8. V.A. Bobkov (2016). Navigation of an underwater robot by using stereo images. Mehatronika, avtomatizacija , upravlenie. Vol. 17, No. 2. P. 101-109.

9. Henriksen, Lars. (1994). Real-time underwater object detection based on an electrically scanned highresolution sonar. In Proceedings of the Symposium on Autonomous Underwater Vehicle Technology. P. 99-104.

10. V.F. Filaretov, D.A. Juhimec, Je.Sh. Mursalimov, I.E. Tufanov (2014). A new method of contour motion control AUUV. Mehatronika, avtomatizacija, upravlenie. No. 8. P. 46-56.

11. A.A. Kushnerik, D.N. Mihajlov, N.S. Sergienko, A.F. Shherbatjuk, V.A Goj, I.E Tufanov, F.S. Dubrovin (2014). Marine robotic complex, including Autonomous unmanned underwater and water vehicles. Mehatronika, avtomatizacija, upravlenie. No. 3. P. 67-72.

12. B.I. Filppov (2016). Energy calculation of hydroacoustic communication lines. Vestnik AGTU. Serija: Upravlenie, vychislitel'naja tehnika i informatika. No. 3. P. 67-77.

13. B.I. Filippov, G.A. Chernetsky (2017). Principles of hardware implementation of the range measurement system in hydroacoustic channels. Radiotekhnika. No. 3. P. 40-49.

14. B.I. Filippov (2019) Architecture of a short-base hydroacoustic navigation system for bringing the underwater vehicle to the docking module. Mechatronics, automation, control. Vol. 20, No. 3. P. 152-161.

15. B.I. Filippov, A.O. Kozhaeva (2019) Determination of the slope distance in the equipment of the high-frequency hydroacoustic system for bringing the underwater vehicle to the docking module. Radiotekhnika. Vol. 83, No. 3. P. 84-95.

16. L.E. Varakin L.E. (1985). Communication systems with noisetype signals. Moscow: Radio i svjaz'. 384 p.

17. Mel'nikov Ju. N. (1973). Dostovernost' informacii v slozhnyh sistemah Reliability of information in complex systems. Moscow: Sov. Radio. 317 p.

18. Piterson U., Ujeldon Je. (1976). The codes correcting errors. Moscow: Mir. 594 p.

19. Penin P.I. (1976). Transmission system of digital information. Moscow: Sov. Radio. 294 p.

20. Filippov B.I. (2016). Features of synchronization of the equipment of communication in the systems of hydroacoustic telemetry. Vestnik PGTU. Serija radiotehnicheskie i infokommunikacionnye sistemy. No. 3. P. 31-44.

21. GOST 17422-82. Systems of data transmission. Speeds of data transmission and key parameters of noiseproof cyclic codes. 


\title{
ВЫБОР СИГНАЛОВ ДЛЯ ГИДРОАКУСТИЧЕСКОЙ НАВИГАЦИОННОЙ СИСТЕМЫ ПРИВЕДЕНИЯ ПОДВОДНОГО АППАРАТА К СТЫКОВОЧНОМУ МОДУЛю
}

\author{
Филиппов Борис Иванович, Новосибирский государственный технический университет, Новосибирск, Россия, \\ filippov-boris@rambler.ru
}

\section{Аннотация}

Предлагаемая работа является первой частью общей работы по разработке структуры гидроакустической навигационной системы приведения (ГНСП) автономного подводного аппарата (АПА) к стыковочному модулю (СМ). Вторая (заключительная) часть будет опубликована в следующем номере журнала. Целью этой работы является выбор сигналов для построения ГНСП, обеспечивающей приведение в ближней зоне на дистанциях, не превышающих 300 м, АПА и его стыковку с носителем. Для чего осуществляется взаимное определение дистанции и углового положения СМ носителя и АПА относительно друг друга. Определение взаимных угловых координат осуществляется с использованием ГНСП с короткой и ультракороткой базой. С точки зрения простоты предпочтительной для реализации является ГНСП с короткой базой. Но ее установка на АПА может оказаться невозможной из-за относительно малых размеров аппарата, и на АПА должна устанавливаться ГНСП с ультракороткой базой. ГНСП с короткой базой может быть установлена на стыковочном модуле. Поскольку нет оснований предполагать высокую скорость изменения фазовой характеристики разрабатываемого высокочастотного канала приведения, поэтому интервал стационарности фазовой характеристики должен быть существенно больше длительности символа на скорости передачи 4 кБит/с, то представляется целесообразным осуществлять обмен данными измерений между АПА и СМ в составе ГНСП методом дискретной относительной фазовой модуляции (ДОФМ). Прием сигналов осуществлять субоптимальным некогерентным приемником, на входе которого осуществляется глубокое ограничение входного сигнала. Показано, что в совмещенной информационно-навигационной системе целесообразно: применить в качестве навигационных сигналы данных, которыми обмениваются АПА и СМ по результатам взаимного измерения навигационных параметров; осуществлять обмен данными между АПА и СМ методом ДОФМ со скоростью V = 4 кБит/с; передачу блока данных осуществлять с применением корректирующего блочного циклического кода (224,200); применить для приема блока данных разнесенный прием в сочетании с мажоритарным декодированием символов, после чего исправлять ошибки в блоке данных с помощью кода, и сопровождать выдачу данных пользователю признаком обнаружения кодом ошибок в блоке.

Ключевые слова: гидроакустическая навигационная система приведения, автономный подводный аппарат, стыковочный модуль, навигационные параметры.

\section{Литература}

І. Филиппов Б.И. Цифровая передача информации в системах гидроакустической телеметрии. Саратов: Ай Пи Ар Медиа, 2019. 290 с.

2. Бреховских Л.М., Лысанов Ю.П. Теоретические основы акустики океана. Л.: Гидрометеоиздат. 1982. 264 с.

3. Агеев М.Д.,Касаткин Б.А., Киселев Л.В. Автоматические плдводные аппараты. Л.: Судостроение, 198І. 224 с.

4. Филаретов В.Ф. Юхимец, Д.А. Способ формирования программного управления скоростным режимом движения подводного аппарата по произвольным пространственным траекториям с заданной динамической точностью // Известия РАН. Теория и системы управления. 20 ІІ. № 4. C. $167-170$.

5. Киселев Л.В. Организация пространственного движения автономного подводного аппарата при траекторном обследовании объектов, областей физических полей. Автореферат диссертации на соискание ученой степени доктора технических наук. спец. 05.13.01. 1997.

6. Филаретов В.Ф., Лебедев А.В., Юхманеи Д.А. Устройства и системы управления подводных роботов. М.: Наука. 2005. 213 с.

7. Кабанов Д.С. Синтез алгоритма оптимального программно-позиционного управления многорежимным автоматическим подводным аппаратом // Мехатроника, автоматизация, управление. 20I4. № I. С. 60-66.

8. Бобков В.А. Навигация подводного робота по стереоизображениям // Мехатроника, автоматизация, управление. 2016. Том 17. №2. С. I0I-109.

9. Henriksen, Lars. Real-time underwater object detection based on an electrically scanned highresolution sonar // In Proceedings of the Symposium on Autonomous Underwater Vehicle Technology. 1994. P. 99-104.

10. Филаретов В.Ф., Юхимец, Д.А., Мурсалимов Э.Ш., Туфанов И.Е. Новый метод контурного упрвления движением АНПА // Мехатроника, автоматизация, управление. 2014. № 8. С. 46-56.

ІІ. Кушнерик А.А., Михайлов Д.Н., Сергиенко Н.С. Щербатюк А.Ф., Гой В.А., Туфанов И.Е., Дубровин Ф.С. Морской робототехнический комплекс, включающий автономные необитаемые подводный и водный аппараты // Мехатроника, автоматизация, управление. 2014 . № 3. С. 67-72.

12. Филиппов Б.И. Энергетический расчёт гидроакустических линий связи // Вестник АГТУ. Серия: Управление, вычислительная техника и информатика. 2016. № 3. С. 67-77.

13. Филиппов Б.И., Чернецкий Г.А. Принципы аппаратурной реализации системы измерения дальности в гидроакустических каналах // Радиотехника. 2017. № 3. С. $40-49$.

14. Филиппов Б.И. Архитектура гидроакустической навигационной системы с короткой базой для приведения подводного аппарата к стыковочному модулю // Мехатроника, автоматизация, управление. 2019. Т. 20, № 3. С. I52-16I.

15. Филиппов Б.И., Кожаева А.О. Определение наклонного расстояния в аппаратуре высокочастотной гидроакустической системе приведения подводного аппарата к стыковочному модулю // Радиотехника. 2019. Т. 83, № 3. С 84-95.

16. Варакин Л.Е. Системы связи с шумоподобными сигналами. М.: Радио и связь. 1985. 384 с.

17. Мельников Ю.Н. Достоверность информации в сложных системах. М.; Сов. Радио. 1973. 317 с.

18. Питерсон У., Уэлдон Э. Коды, исправляющие ошибки. Пер. с англ. М.: Мир. 1976. 594 с.

19. Пенин П.И. Системы передачи цифровой информации. Учебное пособие для вузов. М.: Сов. радио 1976. 294 с.

20. Филиппов Б.И. Особенности синхронизации аппаратуры связи в системах гидроакустической телеметрии // Вестник ПГТУ. Серия радиотехнические и инфокоммуникационные системы. 2016. № 3. С. 3I-44.

2І. ГОСТ 17422-82. Системы передачи данных. Скорости передачи данных и основные параметры помехоустойчивых циклических кодов. 